\title{
Analysis of the antitumor activity of gemcitabine and carboplatin against ovarian clear-cell carcinoma using the DNA damage marker $\gamma \mathrm{H} 2 \mathrm{AX}$
}

This article was published in the following Dove Press journal:

OncoTargets and Therapy

16 July 2013

Number of times this article has been viewed

\section{Eriko Takatori ${ }^{1}$ \\ Tadahiro Shoji ${ }^{\prime}$ \\ Takashi Sawai \\ Akira Kurose ${ }^{3}$ \\ Toru Sugiyama' \\ 'Department of Obstetrics and Gynecology, ${ }^{2}$ Department of Pathology, Iwate Medical University, Morioka, Japan; ${ }^{3}$ Department of Anatomic Pathology, Hirosaki University, Hirosaki, Japan}

Background: Differences in the incidence and type of DNA damage induced by antitumor agents for ovarian clear-cell carcinoma (CCC) were determined in two CCC cell lines, using $\gamma \mathrm{H} 2 \mathrm{AX}$.

Materials and methods: The antitumor activity of gemcitabine (GEM) and carboplatin (CBDCA) were examined using cultured cell lines of CCC (OVISE and RMG-I). Each cell line was treated with GEM and CBDCA, the cells were collected, fixed, and then reacted with anti- $\gamma \mathrm{H} 2 \mathrm{AX}$ antibody. $\gamma \mathrm{H} 2 \mathrm{AX}$ and nuclear DNA were then simultaneously detected by flow cytometry using fluorescein isothiocyanate and propidium iodide, respectively, to determine the amounts of $\gamma \mathrm{H} 2 \mathrm{AX}$ formed in each cell-cycle phase.

Results: After administration of GEM, both cell lines showed DNA damage and cell-cycle arrest in the $\mathrm{S}$ and $\mathrm{G}_{2} / \mathrm{M}$ phases, and increased apoptosis. Similarly, with CBDCA, OVISE showed S- and $\mathrm{G}_{2} / \mathrm{M}$-phase arrest, while RMG-I showed $\mathrm{G}_{2} / \mathrm{M}$-phase arrest.

Conclusion: The mechanism of action of GEM and CBDCA in CCC cell lines was elucidated using $\gamma \mathrm{H} 2 \mathrm{AX}$ as a DNA damage marker. Our findings suggested that concomitant use of GEM plus CBDCA may be effective in the treatment of CCC.

Keywords: $\gamma \mathrm{H} 2 \mathrm{AX}$, clear-cell carcinoma, ovarian cancer, DNA damage, apoptosis, gemcitabine, carboplatin

\section{Introduction}

Ovarian clear-cell carcinoma (CCC), a subtype of epithelial ovarian cancer, is relatively less sensitive to chemotherapy, and is therefore classified as a refractory ovarian cancer. ${ }^{1}$ It has been shown that a combination of carboplatin (CBDCA) and paclitaxel (PTX), a standard therapy for ovarian cancer, ${ }^{2,3}$ is effective against serous adenocarcinoma and endometrioid adenocarcinoma, with a response rate of approximately $75 \%$, while CCC shows lower response rates, ranging from $18 \%$ to $50 \%{ }^{4}$ The incidence of CCC has been increasing and is now estimated to be $23 \%$ in Japan, while that in Europe is reported to be 5\%-6\%. No treatment has been established yet for this histological subtype of ovarian cancer. Histopathology remains the gold standard for classifying epithelial ovarian cancer into subgroups; however, there is emerging evidence indicating differences in the genetic and molecular profiles among these cancers. On the other hand, there is no international consensus regarding the necessity of establishing treatment strategies based on the histological subtype. Current chemotherapeutic options for ovarian cancer include drugs inducing DNA damage (eg, cisplatin and CBDCA), microtubule inhibitors (eg, PTX), topoisomerase inhibitors (eg, polyethylene glycolated liposomal
Correspondence: Tadahiro Shoji

Department of Obstetrics and

Gynecology, School of Medicine, Iwate

Medical University, 19-I Uchimaru,

Morioka, Iwate 020-8505, Japan

$\mathrm{Tel}+8 \mathrm{I} 1965 \mathrm{I} 5 \mathrm{III}$

Fax +81196221900

Email tshoji@iwate-med.ac.jp 
doxorubicin, topotecan, irinotecan), and antimetabolites (eg, gemcitabine [GEM] and 5-fluorouracil).

Recently, it has become apparent that phosphorylation of histone $\mathrm{H} 2 \mathrm{AX}$, one of the variants of the nucleosome core histone $\mathrm{H} 2 \mathrm{~A}$, can serve as a sensitive and reliable marker of DNA damage (Figure 1A). More specifically, DNA damage, particularly that involving the formation of DNA double-strand breaks, induces phosphorylation of histone H2AX on Ser-139; phosphorylated H2AX is termed $\gamma \mathrm{H} 2 \mathrm{AX}$ (Figure 1B). ${ }^{5}$ Dot $\gamma \mathrm{H} 2 \mathrm{AX}$, detectable using $\gamma \mathrm{H} 2 \mathrm{AX}-$ specific antibody, is considered to be a specific marker of DNA damage. Therefore, DNA damage can be detected by immunocytochemistry. ${ }^{6}$

We reported previously that $\gamma \mathrm{H} 2 \mathrm{AX}$ is a useful marker for the evaluation of DNA damage and apoptosis. ${ }^{7}$ In this study, we focused on $\gamma \mathrm{H} 2 \mathrm{AX}$ as a marker of DNA damage to examine the cellular effects of GEM and CBDCA on CCC in terms of cell-cycle arrest, DNA damage, and induction of apoptosis. In addition, chemotherapeutic regimens that are likely to be effective in the treatment of CCC are discussed.

\section{Materials and methods Cell culture}

We used two CCC cell lines (OVISE and RMG-I) obtained from the Health Science Research Resources Bank (Osaka, Japan). OVISE was established from a patient with metastatic disease after completion of six cycles of a platinum-based

A

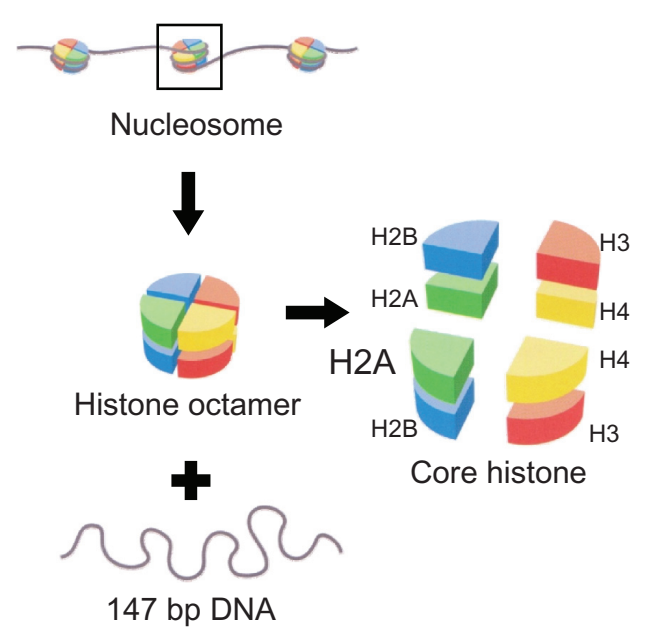

combination therapy, and was cultured in dishes (BD, Franklin Lakes, NJ, USA) containing Roswell Park Memorial Institute 1640 medium (Sigma-Aldrich, St Louis, MO, USA) supplemented with $10 \%$ fetal bovine serum. RMG-I was established from a chemotherapy-naïve patient with ascites, and was reported to show primary platinum resistance. ${ }^{8}$ RMG-I was grown in dishes (BD) in Ham F-12 medium supplemented with $10 \%$ fetal bovine serum. For both cell lines, the medium was supplemented with $100 \mathrm{U} / \mathrm{mL}$ penicillin and $100 \mu \mathrm{g} / \mathrm{mL}$ streptomycin (Meiji Seika, Tokyo, Japan). All cell lines were maintained at $37^{\circ} \mathrm{C}$ in a humidified atmosphere of $5 \% \mathrm{CO}_{2}$ in air.

\section{Drug}

GEM was dissolved in dimethyl sulfoxide (Sigma-Aldrich); the final concentration of dimethyl sulfoxide in the culture medium never exceeded $0.1 \%(\mathrm{w} / \mathrm{v})$. CBDCA was dissolved in phosphate-buffered saline (PBS). The concentrations of GEM and CBDCA were set to correspond to the blood concentration at a standard clinical dose. Clinical maximum drug concentration and minimum effective concentrations of GEM and CBDCA are $25 \mu \mathrm{g} / \mathrm{mL}$ and $5 \mathrm{ng} / \mathrm{mL}$, and $55 \mu \mathrm{g} / \mathrm{mL}$ and $10 \mu \mathrm{g} / \mathrm{mL}$, respectively.

\section{Immunohistochemistry}

Both the cells floating in the medium and the cells that remained attached after trypsinization were collected and fixed with $1 \%$ methanol-free formaldehyde (Polysciences,

B

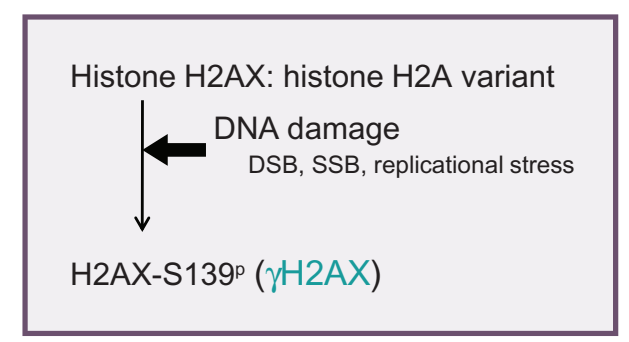

Figure I (A) Nucleosomes, units of chromatin, consist of core histones wrapped in 146 bp of DNA and linker DNA. Core histones are octamers designated as H2A, H2B, $\mathrm{H} 3$, and $\mathrm{H} 4$. Not all nucleosomes include typical histone octamers containing $\mathrm{H} 2 \mathrm{~A}, \mathrm{H} 2 \mathrm{~B}, \mathrm{H} 3$, and $\mathrm{H} 4$. In some parts of the chromosome, specific histones are replaced by histone variants that are slightly different histones involved in the local chromosome function. Histone $\mathrm{H} 2 \mathrm{AX}$ is a variant of histone $\mathrm{H} 2 \mathrm{~A}$. $\mathrm{H} 2 \mathrm{AX}$ is known to be highly concentrated in areas of DNA damage. (B) When DNA damage occurs, serine 139 of histone H2AX in the chromatin on both sides of the damaged site is phosphorylated. Phosphorylated histone $\mathrm{H} 2 \mathrm{AX}$ is referred to as $\gamma \mathrm{H} 2 \mathrm{AX}$.

Abbreviations: DNA, deoxyribonucleic acid; DSB, double strand break; SSB, single strand break. 
Warrington, PA, USA) in PBS at $0^{\circ} \mathrm{C}$ for 15 minutes and postfixed with $80 \%$ ethanol for at least 2 hours at $-20^{\circ} \mathrm{C}$. The fixed cells were washed twice in PBS and suspended in a $1 \%(\mathrm{w} / \mathrm{v})$ solution of bovine serum albumin (SigmaAldrich) in PBS, to suppress nonspecific antibody binding. The cells were then incubated in $100 \mu \mathrm{L}$ of $1 \%$ bovine serum albumin containing 1:100 diluted antiphosphohistone H2AX (Ser-139) monoclonal antibody (Upstate, Lake Placid, NY, USA) for 2 hours at room temperature, washed twice with PBS, and resuspended in $100 \mu \mathrm{L}$ of 1:20 diluted fluorescein isothiocyanate-conjugated $\mathrm{F}\left(\mathrm{ab}{ }^{\prime}\right)_{2}$ fragment of goat antimouse immunoglobulin (Dako, Glostrup, Denmark) for 30 minutes at room temperature in the dark. The cells were then counterstained with $5 \mu \mathrm{g} / \mathrm{mL}$ propidium iodide (Sigma-Aldrich) in the presence of $100 \mu \mathrm{L}$ of ribonuclease $\mathrm{A}$ (Sigma-Aldrich) for 30 minutes.

\section{Fluorescence measurements by flow cytometry}

The fluorescein isothiocyanate (green) and propidium iodide (red) fluorescences of individual cells in suspension induced by excitation with a $488 \mathrm{~nm}$ argon ion laser were measured using a FACScan flow cytometer (BD). The green and red fluorescences from each cell were separated and quantified using standard optics and CellQuest software (BD). Ten thousand cells were measured per sample. All experiments were repeated at least three times.

After $\gamma \mathrm{H} 2 \mathrm{AX}$ and DNA staining, the DNA content and $\gamma \mathrm{H} 2 \mathrm{AX}$ content determined by flow cytometry were represented on the $x$ and $y$ axes, respectively. The $\gamma \mathrm{H} 2 \mathrm{AX}$ content in each cell cycle was determined, so as to allow examination of the relationships between cell kinetics and the DNA damage induced by antitumor agents.

\section{Results GEM}

In the OVISE cells, treatment with $5 \mathrm{ng} / \mathrm{mL}$ or more of GEM mainly caused DNA damage in cells of the early S-phase. After exposure to $100 \mathrm{ng} / \mathrm{mL}$ or more of GEM, the S-phase cells showing DNA damage underwent apoptosis. Similarly, in the RMG-I cells, DNA damage was primarily seen in the early S-phase cells following exposure to $5 \mathrm{ng} / \mathrm{mL}$ or more of GEM. Treatment with $100 \mathrm{ng} / \mathrm{mL}$ or $1 \mu \mathrm{g} / \mathrm{mL}$ GEM induced DNA damage not only in S-phase cells but also in $\mathrm{G}_{2} / \mathrm{M}$ phase cells. These cells, however, did not undergo apoptosis (Figure 2A). To investigate the time course of the changes, both cell lines were treated with GEM at the minimum concentration causing DNA damage $(5 \mathrm{ng} / \mathrm{mL})$ for different periods of time. In the OVISE cells, DNA damage was mainly confined to S-phase cells after exposure to GEM for 24 hours or more. However, after exposure for 48 hours or more, DNA damage also extended to the cells of the $\mathrm{G}_{2} / \mathrm{M}$ phase. The S-phase cells with DNA damage underwent apoptosis after exposure to GEM for 48 hours or more, while the number of cells in the $\mathrm{G}_{1}$ phase gradually decreased and there was S-phase arrest. Moreover, $\mathrm{G}_{2} / \mathrm{M}$-phase cells showing DNA damage remained viable without undergoing apoptosis. In RMG-I cells, marked DNA damage was observed in the S-phase cells after 24 hours of exposure to GEM, although the cells underwent apoptosis after 72 hours' exposure to GEM. Similar to the OVISE cells, the gradual decreases in the number of cells in the $G_{1}$ phase and S-phase arrest were also noted in RMG-I cells. $\mathrm{G}_{2} / \mathrm{M}$-phase cells showing DNA damage remained viable without apoptosis even after 120 hours of exposure to GEM, and $\mathrm{G}_{2} / \mathrm{M}$-phase arrest was induced (Figure 2B).

\section{CBDCA}

DNA damage in the $\mathrm{S}$ phase was seen gradually after exposure to CBDCA for 24 hours in the OVISE and RMG-I lines at $1 \mu \mathrm{g} / \mathrm{mL}$ and $10 \mu \mathrm{g} / \mathrm{mL}$, respectively (Figure $3 \mathrm{~A}$ ). Subsequently, cells with damaged DNA underwent apoptosis. Gradually, both cell lines showed DNA damage in the $\mathrm{G}_{2} / \mathrm{M}$ phase and underwent apoptosis. OVISE showed $\mathrm{S}$ - and $\mathrm{G}_{2} / \mathrm{M}$-phase arrest, while RMG-I showed $\mathrm{G}_{2} / \mathrm{M}$-phase arrest (Figure 3B). ${ }^{9}$

\section{Discussion}

Numerous distinct dots of $\gamma \mathrm{H} 2 \mathrm{AX}$ are usually observed when cells are pretreated with antitumor agents and immunohistochemically stained using $\gamma \mathrm{H} 2 \mathrm{AX}$ antibodies. Each of these dots is considered to correspond to a site of DNA damage. ${ }^{6}$ In apoptotic cells, because of DNA fragmentation, nuclear fragments showing strong staining of $\gamma \mathrm{H} 2 \mathrm{AX}$ are commonly observed. Thus, DNA damage and apoptosis can be visualized using $\gamma \mathrm{H} 2 \mathrm{AX}$ as an indicator. In a cell, all chromosomal DNA is replicated and the amount of DNA doubles during the $\mathrm{S}$ phase; then cell division occurs during the $\mathrm{M}$ phase to produce two daughter cells that initiate a new cell cycle. After immunofluorescence staining of $\gamma \mathrm{H} 2 \mathrm{AX}$ and counterstaining of DNA, histograms were constructed by plotting the amount of DNA and amount of $\gamma \mathrm{H} 2 \mathrm{AX}$ in the cells, determined by flow cytometry, on the $x$ and $y$ axes, respectively, to detect the amount of $\gamma \mathrm{H} 2 \mathrm{AX}$ formed in each cell-cycle phase; this allowed a visual estimation of 
A Control

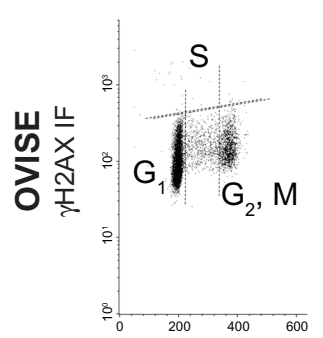

$0.1 \mathrm{ng} / \mathrm{mL} \quad 1 \mathrm{ng} / \mathrm{mL}$

$5 \mathrm{ng} / \mathrm{mL}$

$10 \mathrm{ng} / \mathrm{mL}$

$100 \mathrm{ng} / \mathrm{mL}$

$1 \mu \mathrm{g} / \mathrm{mL}$

DNA content
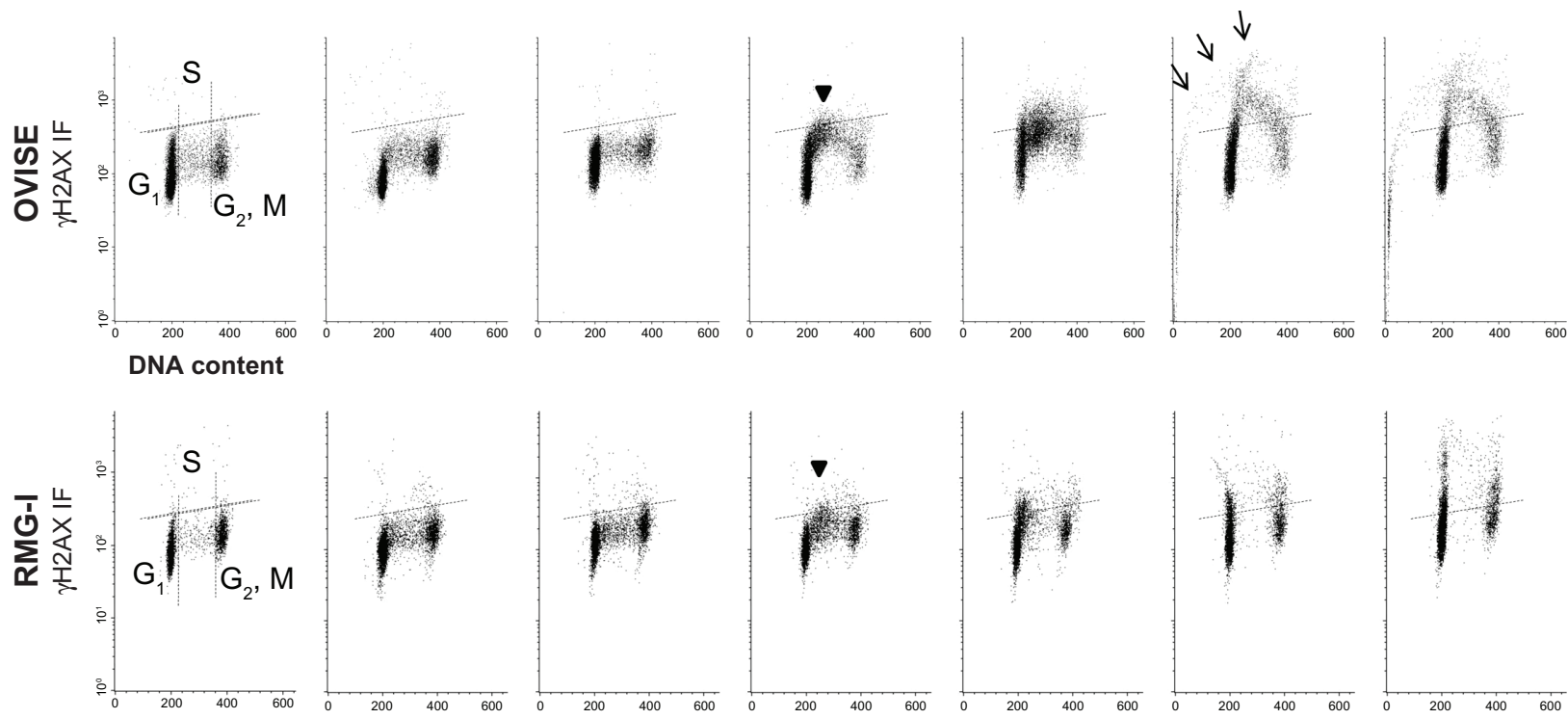

B

Control

$24 \mathrm{~h}$

$48 h$

$72 \mathrm{~h}$

$96 \mathrm{~h}$

$120 \mathrm{~h}$
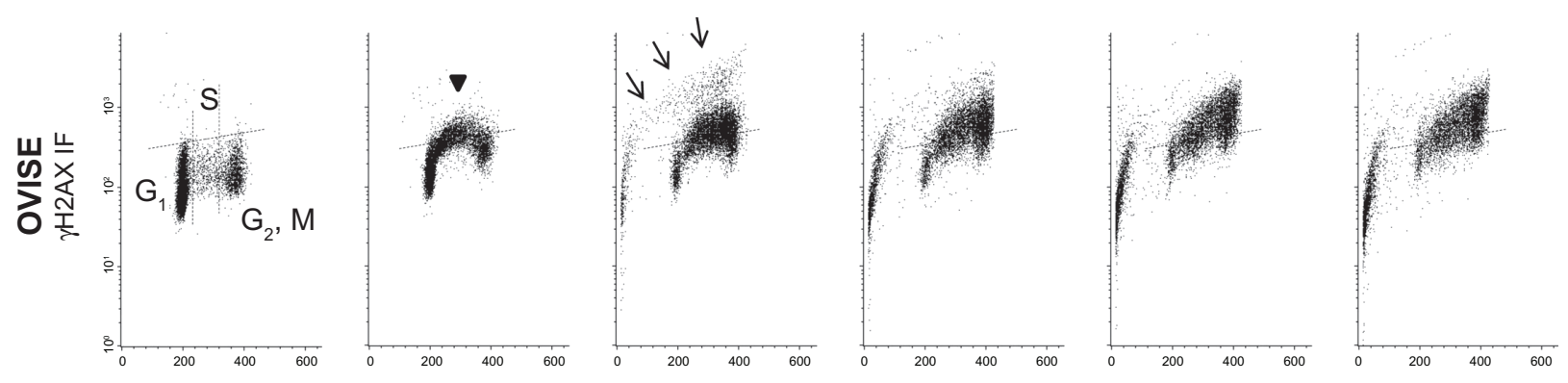

DNA content
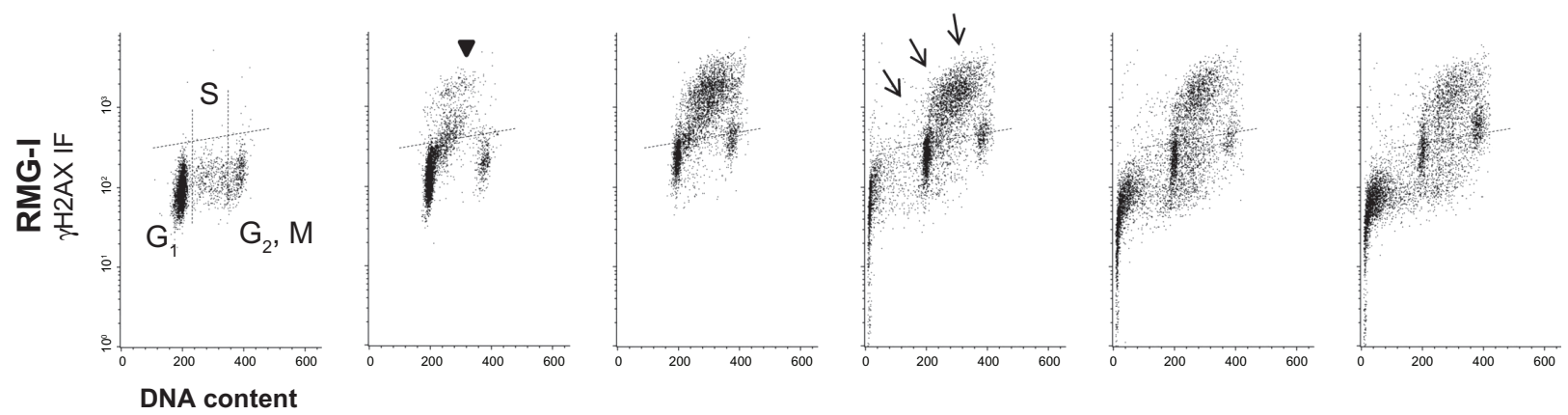

Figure 2 (A and B) Bivariate distributions (DNA content vs $\gamma \mathrm{H} 2 \mathrm{AX}$ ) in the clear-cell carcinoma cell lines OVISE and RMG-l, treated with gemcitabine. The dotted lines indicate the upper level of $\gamma \mathrm{H} 2 \mathrm{AX}$ immunofluorescence in $95 \%$ of cells in the untreated (control) culture. Arrowheads indicate elevation in the immunofluorescence intensity of $\gamma \mathrm{H} 2 \mathrm{AX}$, suggestive of DNA damage. Arrows indicate apoptotic cell populations with marked increase in the amount of $\gamma \mathrm{H} 2 \mathrm{AX}$ and gradual decrease in DNA. (A) Both cell lines were treated with various concentrations of gemcitabine for 24 hours. Both cell lines exhibited DNA damage in S-phase cells at the minimum concentration of $5 \mathrm{ng} / \mathrm{mL}$. In the OVISE line, apoptosis was induced at concentrations of $100 \mathrm{ng} / \mathrm{mL}$ or higher. RMG-I cells remained with DNA damage. (B) Both cell lines were treated with $5 \mathrm{ng} / \mathrm{mL}$, calculated as the minimum concentration inducing DNA damage, for various reaction times. S-phase cells of OVISE showing DNA damage underwent apoptosis after 48 hours. In addition, S- and G/M-phase arrest was observed. DNA damage was induced in the S-phase cells of RMG-I after 24 hours, and the cells showing DNA damage underwent apoptosis after 72 hours. Furthermore, cell-cycle arrest occurred in the $S$ - and $G_{2} / M$ phases.

Abbreviations: DNA, deoxyribonucleic acid; S, synthesis phase; $G_{1}$, Gap I phase; $G_{2}$, Gap 2 phase; M, mitotic phase; h, hours.

the extent of DNA damage caused by antitumor agents and examination of changes in the cellular kinetics. In this immunohistochemical $\gamma \mathrm{H} 2 \mathrm{AX}$-detection method, DNA damage can be detected with high sensitivity at much lower concentrations of the necessary agents than in the comet assay, and the extent of DNA damage can be correlated with the phase of the cell cycle. ${ }^{10}$

Combination chemotherapy with PTX and CBDCA is established as the gold standard for ovarian cancer. This therapy, however, is not sufficiently effective for $\mathrm{CCC}$, and it 
A Control $\quad 1 \mathrm{ng} / \mathrm{mL} \quad 10 \mathrm{ng} / \mathrm{mL} \quad 100 \mathrm{ng} / \mathrm{mL} \quad 1 \mu \mathrm{g} / \mathrm{mL} \quad 10 \mu \mathrm{g} / \mathrm{mL} \quad 50 \mu \mathrm{g} / \mathrm{mL}$
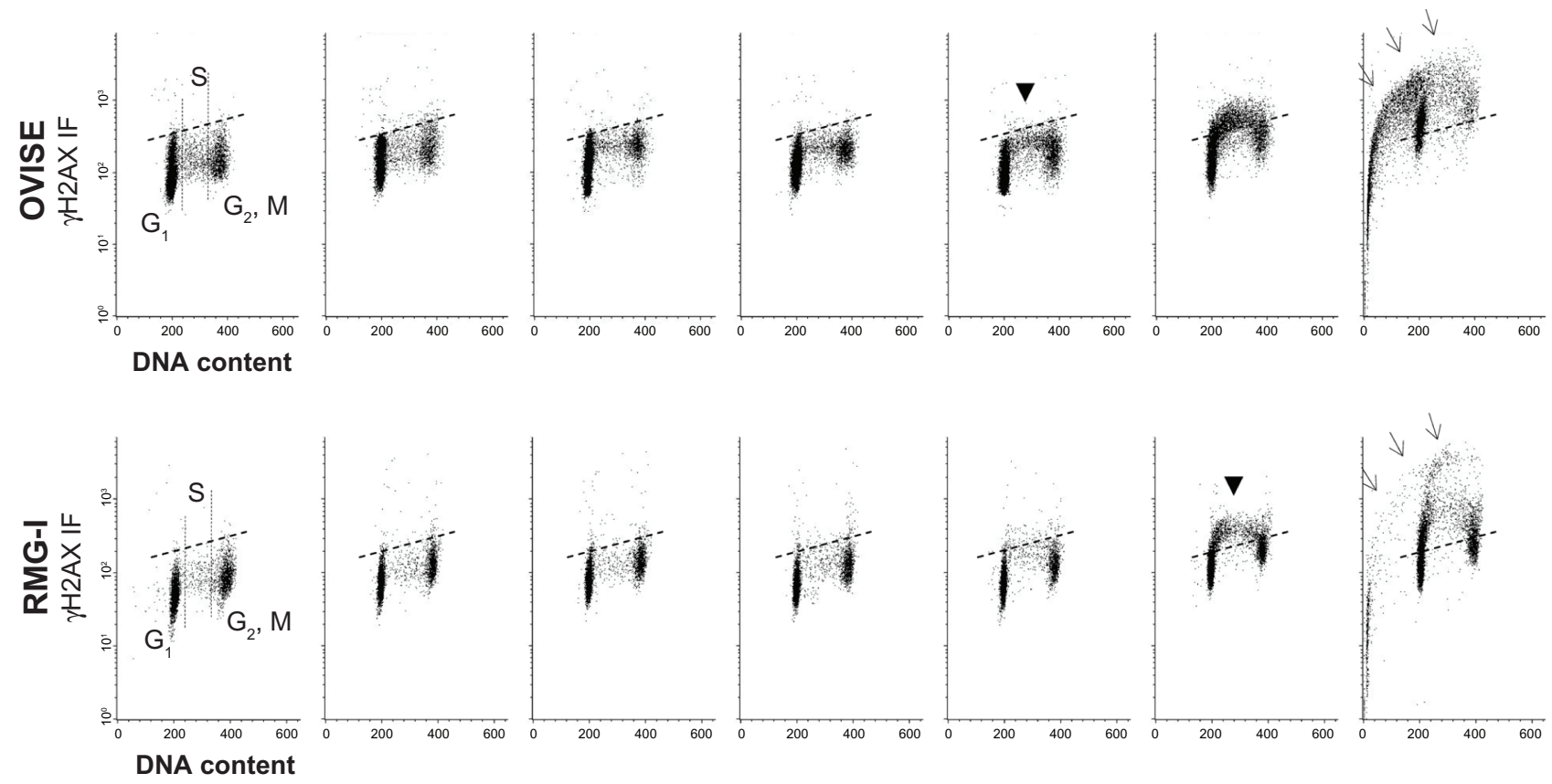

B

Control

$24 \mathrm{~h}$

$48 \mathrm{~h}$

$72 \mathrm{~h}$

$96 \mathrm{~h}$

$120 \mathrm{~h}$
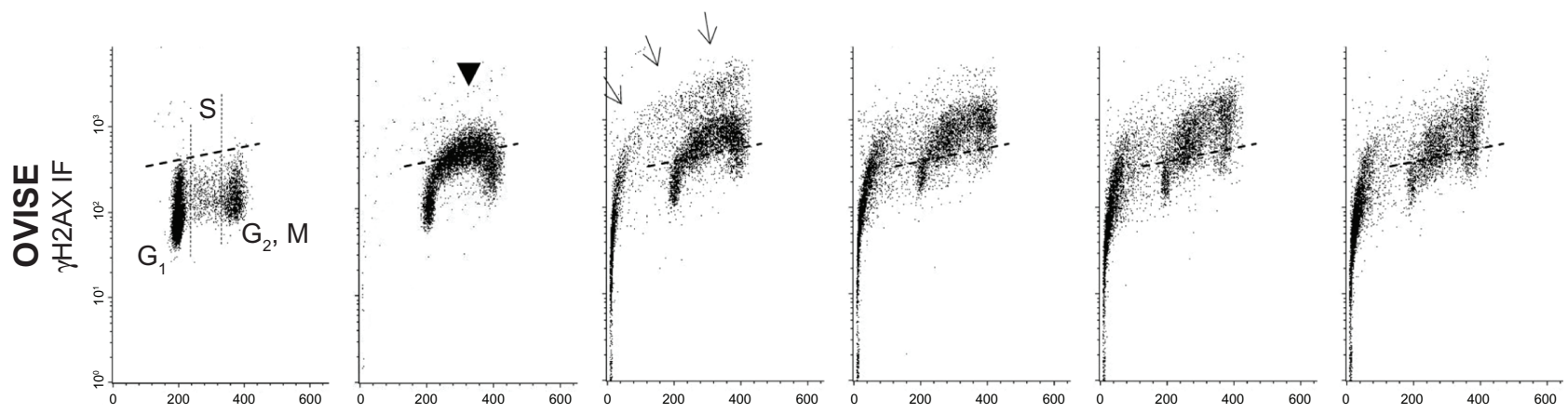

DNA content
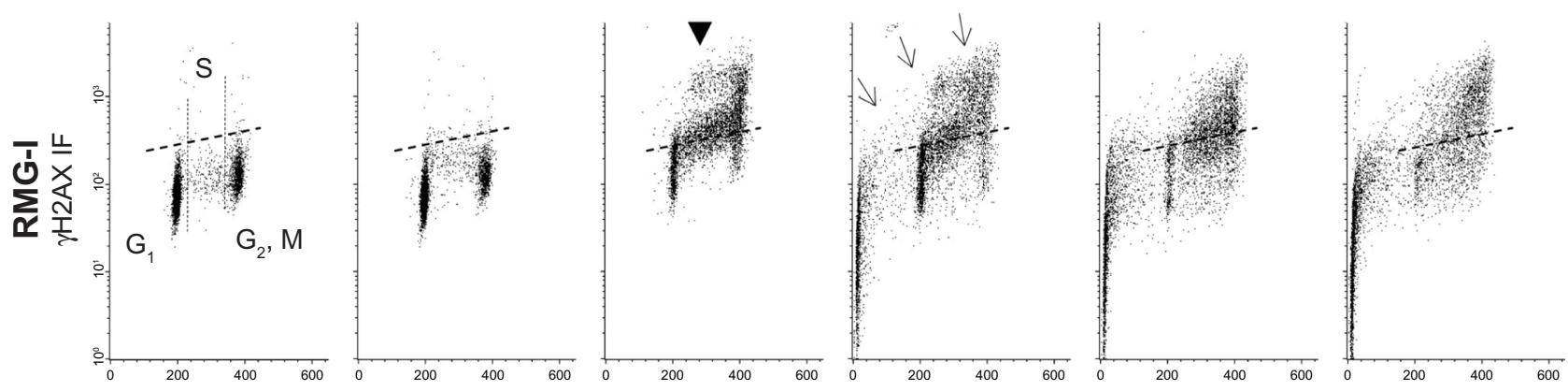

Figure 3 (A and B) Bivariate distributions (DNA content vs $\gamma \mathrm{H} 2 \mathrm{AX}$ ) of OVISE and RMG-I cell lines, treated with carboplatin. The dotted lines indicate control. Arrowheads and arrows indicate DNA damage and apoptosis, respectively. (A) Both cell lines were treated with various concentrations of carboplatin for 24 hours. DNA damage was observed in the S-phase cells at I $\mu \mathrm{g} / \mathrm{mL}$ and $10 \mu \mathrm{g} / \mathrm{mL}$ concentrations in OVISE and RMG-I, respectively. DNA damage was found in both cell lines at every cell cycle as the concentration increased, and apoptosis occurred at a concentration of $50 \mu \mathrm{g} / \mathrm{mL}$. More cells remained free of DNA damage in RMG-I than in OVISE. (B) Both cell lines were treated with I $\mu \mathrm{g} / \mathrm{mL}$, the minimum concentration inducing DNA damage in either cell line, for various reaction times. In OVISE, S-phase cells with DNA damage progressed to apoptosis after 48 hours. DNA damage was also found in $\mathrm{G}_{2} / \mathrm{M}$-phase cells after 48 hours, but most did not progress to apoptosis. $\mathrm{S}$ - and $\mathrm{G}_{2} / \mathrm{M}$-phase arrests were observed. DNA damage was found in S- and $G_{2} / M$-phase cells after 48 hours in RMG-I. The S-phase cells with DNA damage progressed to apoptosis 72 hours later, but $G_{2} / M$-phase cells showing DNA damage remained. S- and $G_{2} / M$-phase arrests were observed.

Abbreviations: DNA, deoxyribonucleic acid; S, synthesis phase; $G_{1}$, Gap I phase; $G_{2}$, Gap 2 phase; M, mitotic phase; h, hours. 
has been pointed out that individualization of chemotherapy based on the histological subtypes is needed for this type of cancer. ${ }^{4}$ GEM has proved to be effective in patients with ovarian cancer, ${ }^{11,12}$ and a publication-based application of GEM was submitted in September 2010 in Japan. In this study, we attempted to demonstrate the efficacy of GEM and CBDCA, and examine the possibility of expanding the treatment options for patients with $\mathrm{CCC}$, for whom the current treatment options are limited.

GEM is an antimetabolite used to treat recurrent ovarian cancer that is known to exert its antitumor activity via becoming incorporated into the cellular DNA. In both the CCC cell lines used in this study, GEM induced marked DNA damage and cell-cycle arrest in the S phase, probably as a result of the GEM-induced stalled replication forks. However, many cells with DNA damage remained viable even after exposure to GEM for 120 hours, indicating that GEM had only a weak cytocidal effect on the CCC cells.

The results of the study showed that GEM exerted a weaker antitumor effect on the RMG-I cells than on the OVISE cells. Possible reasons for this include the higher percentage of $\mathrm{G}_{0} / \mathrm{G}_{1}$ cells and lower percentage of S-phase cells in the RMG-I cell line. A relatively low proportion of cells in the S phase is generally observed in CCCs, and may account for the insufficient antitumor effect of GEM monotherapy in patients with this type of ovarian cancer. Unlike in human myelogenous leukemia cell lines, ${ }^{13}$ GEM caused cell-cycle arrest not only in the $\mathrm{S}$ phase but also in the $\mathrm{G}_{2} / \mathrm{M}$ phase in the $\mathrm{CCC}$ cell lines. In addition, cells arrested in the $G_{2} / M$ phase of the cell cycle also showed DNA damage. Taking into account the GEM concentrations and the time course of the cellular changes, this may be attributable to the cell-cycle arrest induced at the $\mathrm{G}_{2} / \mathrm{M}$ checkpoint after progression of the S-phase cells showing DNA damage to the $\mathrm{G}_{2}$ phase. Although the factors involved in the phosphorylation of ataxia telangiectasia and $\operatorname{Rad} 3-$ related protein after recognition of DNA damage are not yet clearly defined, it is considered that BRCA1, a human tumorsuppressor gene product, may play a role in the process and is responsible for $\mathrm{G}_{2} / \mathrm{M}$ checkpoint regulation in response to DNA damage. A recent study has shown $B R C A 1$ mutations involved in CCC. ${ }^{14}$ Thus, BRCA1 gene mutations in CCC cell lines may be involved in the cell-cycle arrest at the $\mathrm{G}_{2} / \mathrm{M}$ phase observed in this study.

After CBDCA administration, DNA damage was seen in the $S$ and $\mathrm{G}_{2} / \mathrm{M}$ phases in both cell lines. OVISE contained a remarkable cell population rescued from apoptosis and surviving with DNA damage. On the other hand, most
RMG-I cells with DNA damage underwent apoptosis. These results suggest that cell lines respond differently to platinum agents, ie, RMG-I was cisplatin-resistant but responded to CBDCA.

This study infers that for residual cells in which the cell cycle remains arrested due to DNA damage caused by GEM, effective cytocidal action can theoretically be obtained by additionally or concomitantly administering CBDCA, which exerts effects on any cells in cell-cycle arrest (Table 1). These mechanisms of action for both drugs have already been elucidated in many types of carcinomas other than ovarian CCC. In this paper, the mechanisms of action in CCC are reported. The results obtained suggest that combination therapy with GEM plus CBDCA might be useful in the treatment of CCC. This conclusion was derived from our own study method using flow cytometry with $\gamma \mathrm{H} 2 \mathrm{AX}$ as a marker. In order to establish GEM-plus-CBDCA therapy, which is currently being administered in clinical trials, we considered it to be essential to demonstrate its usefulness not only for other types of carcinomas but also for CCC in basic studies. Moreover, another study is currently being conducted to assess whether there are synergistic effects of GEM plus CBDCA.

Currently, a randomized clinical trial (iPLAS) is ongoing as an intergroup study in Japan to compare the efficacy and safety of GEM plus CBDCA with those of polyethylene glycolated liposomal doxorubicin plus CBDCA in patients with platinum-sensitive, recurrent ovarian cancer. Moleculartargeted agents have come to be increasingly used in chemotherapy for ovarian cancer around the world. However, it is still impossible to use such drugs in clinical settings other than physician-initiated clinical trials in Japan. Therefore, effective treatment of CCC needs to be developed using antitumor drugs covered by health insurance. In this study, we used $\gamma \mathrm{H} 2 \mathrm{AX}$ as an indicator to examine the antitumor effects of GEM and CBDCA on OVISE and RMG-I cells, and the results suggested that combination chemotherapy with GEM plus CBDCA may be effective for CCC. The method employed in this study is convenient and very

Table I Cell kinetics of CCC cells treated with anticancer drugs

\begin{tabular}{clll}
\hline & DNA damage & Apoptosis & Cell cycle arrest \\
\hline GEM & & & \\
OVISE & $\mathrm{S}$ & + & $\mathrm{S}, \mathrm{G}_{2} / \mathrm{M}$ \\
RMG-I & $\mathrm{S}, \mathrm{G}_{2} / \mathrm{M}$ & + & $\mathrm{S}, \mathrm{G}_{2} / \mathrm{M}$ \\
CBDCA & & & \\
OVISE & $\mathrm{S}, \mathrm{G}_{2} / \mathrm{M}$ & + & $\mathrm{S}, \mathrm{G}_{2} / \mathrm{M}$ \\
RMG-I & $\mathrm{S}, \mathrm{G}_{2} / \mathrm{M}$ & + & $\mathrm{G}_{2} / \mathrm{M}$ \\
\hline
\end{tabular}

Abbreviations: CCC, clear cell carcinoma; CBDCA, carboplatin; GEM, gemcitabine; $\mathrm{S}$, synthesis phase; $G_{2}$, Gap 2 phase; M, mitotic phase. 
useful to examine the antitumor effects of anticancer drugs, as it takes only a short time for the effects of the agents to be assessed. In this study, we presented the data regarding single-agent administration of GEM and CBDCA. We are currently conducting a study on the combination, and will report the results in a future paper.

This report provides valid findings that would contribute to improvement of the prognosis of patients with CCC. We anticipate that our findings would also promote the development of further in vitro studies.

\section{Disclosure}

The authors report no conflicts of interest in this work.

\section{References}

1. Sugiyama T, Kamura T, Kigawa J, et al. Clinical characteristics of clear cell carcinoma of the ovary: a distinct histologic type with poor prognosis and resistance to platinum-based chemotherapy. Cancer. 2000;88: 2584-2589.

2. McGuire WP, Hoskins WJ, Brady MF, et al. Cyclophosphamide and cisplatin compared with paclitaxel and cisplatin in patients with stage III and stage IV ovarian cancer. N Engl J Med. 1996;334:1-6.

3. Ozols RF, Bundy BN, Greer BE, et al. Phase III trial of carboplatin and paclitaxel compared with cisplatin and paclitaxel in patients with optimally resected stage III ovarian cancer: a Gynecologic Oncology Group study. J Clin Oncol. 2003;21:3194-3200.

4. Sugiyama T, Fujiwara K. Clear cell carcinoma of the ovary. In: Govindan R, editor. American Society of Clinical Oncology 2007 Educational Book. Alexandria (VA); 2007:318-322.
5. Dickey JS, Redon CE, Nakamura AJ, Baird BJ, Sedelnikova OA, Bonner WM. H2AX:functional roles and potential applications. Chromosoma. 2009;118:683-692.

6. Bonner WM, Redon CE, Dickey JS, et al. GammaH2AX and cancer. Nat Rev Cancer. 2008;8:957-967.

7. Tanaka T, Kurose A, Halicka HD, Huang X, Traganos F, Darzynkiewicz Z. Nitrogen oxide-releasing aspirin induces histone $\mathrm{H} 2 \mathrm{AX}$ phosphorylation, ATM activation and apoptosis preferentially in S-phase cells: involvement of reactive oxygen species. Cell Cycle. 2006;5:1669-1674.

8. Itamochi H, Kigawa J, Sultana H, et al. Sensitivity to anticancer agents and resistance mechanisms in clear cell carcinoma of the ovary. Jpn J Cancer Res. 2002;93:723-728.

9. Takatori E, Shoji T, Kumagai S, Sawai T, Kurose A, Sugiyama T. Are platinum agents, paclitaxel and irinotecan effective for clear cell carcinoma of the ovary? DNA damage detected with $\gamma \mathrm{H} 2 \mathrm{AX}$ induced by anticancer agents. $J$ Ovarian Res. 2012;12:16.

10. Watters GP, Smart DJ, Harvey JS, Austin CA. H2AX phosphorylation as a genotoxicity endpoint. Mutat Res. 2009;679:50-58.

11. Pfisterer J, Plante M, Vergote I, et al. Gemcitabine plus carboplatin compared with carboplatin in patients with platinum-sensitive recurrent ovarian cancer: an intergroup trial of the AGO-OVAR, the NCIC CTG, and the EORTC GCG. $J$ Clin Oncol. 2006;24:4699-4707.

12. Watanabe Y, Koike E, Nakai H, Etoh T, Hoshiai H. Phase II study of single-agent gemcitabine in heavily pretreated Japanese patients with recurrent ovarian cancer. Int J Clin Oncol. 2008;13:345-348.

13. Ewald B, Sampath D, Plunkett W. H2AX phosphorylation marks gemcitabine-induced stalled replication forks and their collapse upon S-phase checkpoint abrogation. Mol Cancer Ther. 2007;6: 1239-1248.

14. Wu JY, Vlastos AT, Pelte MF, et al. Aberrant expression of BARD1 in breast and ovarian cancers with poor prognosis. Int J Cancer. 2006;118: $1215-1226$.
OncoTargets and Therapy

\section{Publish your work in this journal}

OncoTargets and Therapy is an international, peer-reviewed, open access journal focusing on the pathological basis of all cancers, potential targets for therapy and treatment protocols employed to improve the management of cancer patients. The journal also focuses on the impact of management programs and new therapeutic agents and protocols on

\section{Dovepress}

patient perspectives such as quality of life, adherence and satisfaction The manuscript management system is completely online and includes a very quick and fair peer-review system, which is all easy to use. Visit http://www.dovepress.com/testimonials.php to read real quotes from published authors. 